\title{
Aspects of Professionalism, Ethics and Lifelong Learning for Australian ICT Professionals
}

\author{
Bill Davey \\ RMIT University, Australia \\ Arthur Tatnall \\ Victoria University, Australia
}

\begin{abstract}
In a change from 20 years ago, the majority of Information and Communications Technology (ICT) professionals in Australia now have some form of initial tertiary qualification and also understand the need for keeping up-to-date with new technologies, processes and concepts. They thus typically engage in some form of on-going professional development or Lifelong Learning. Not all, however, fully realise the need to keep up with other issues such as ethics and professionalism. In this article we look at what is meant by ICT professionalism, particularly from an Australian perspective, and consider its importance. Professionalism in ICT should be seen as a way of maximising quality and reducing risks. The ICT industry itself is changing and the Australian Computer Society is in the process of developing a new ICT Body of Knowledge, based on specific Technical and also Professional Knowledge. This article examines how the issue of professionalism is handled in Australia in both undergraduate education and lifelong learning of ICT professionals. It gives examples of how ICT professionalism in undergraduate courses is handled, and looks at examples of why and how ICT professionals undertake further education and lifelong learning.
\end{abstract}

\section{Keywords}

Information and communication technology, ICT professionals, professionalism, initial education, lifelong learning

\section{The Australian ICT Industry and the Future}

A recent report to the Australian Commonwealth Government (Department of Communication; Information Technology and the Arts 2006) noted how a highly skilled ICT workforce able to make innovative use of ICT as the key to business productivity improvement had considerable value to Australia (Davey and Tatnall 2008). The report stated that: "The combined impacts of the ageing workforce, changing generational patterns of work and the apparent failure of many employers to upgrade workplace skills could mean that Australia risks being unable to sustain key ICT-based economic capabilities, operations and services in the future" (Department of Communication;

Copyright (C) 2009 Victoria University. This document has been published as part of the Journal of Business Systems, Governance and Ethics in both online and print formats. Educational and non-profit institutions are granted a nonexclusive licence to utilise this document in whole or in part for personal or classroom use without fee, provided that correct attribution and citation are made and this copyright statement is reproduced. Any other usage is prohibited without the express permission of the publisher. Information Technology and the Arts 2006). It identified what it considered as an outmoded and negative perception of ICT occupations and careers as a major concern, pointing to a poor understanding of the diversity of ICT occupations and opportunities and suggesting an urgent need: "... for action to address negative perceptions of ICT careers in the community which lead many young people and those who influence their career 
choices (such as parents, teachers, career advisers) to underestimate the opportunities available in ICT and thus to turn away from considering a career in ICT" (Department of Communication; Information Technology and the Arts 2006).

While the future for ICT professionals appears bright, it is surprising to note this decline in University enrolments across the entire ICT field by comparison with the growing shortage of ICT professionals in the industry (Australian Computer Society 2007b). Much of this decline appears to relate to inaccurate ideas by many people about the nature of ICT careers. Many school students seem to think that an ICT career corresponds solely to technical issues and to computer programming, and that these tasks will soon all be outsourced to India. Those of us in the industry know this to be incorrect, as evidenced by the response by a senior technical executive from IBM at a meeting of Information Technology Professors in the UK to a question about the future of software engineering. He agreed that most of the basic programming jobs would continue to be outsourced to countries like India, but went on to stress that business-related ICT jobs, involving areas such as business analysis and customising solutions for local businesses would and must remain in the country (Thompson 2006; Davey and Tatnall 2008).

A report (Gartner 2005) from a few years ago predicted that by $2010,60 \%$ of people working in ICT would be undertaking business roles based around information, process and relationships. The report lists four main areas of relevant knowledge:

- Technical knowledge. How does this technology work? What are its effects? How does it interact with other technologies? What are its dependencies?

- Business-specific knowledge. What makes this company tick? Business-specific knowledge breaks down further into knowledge of enterprise objectives, operational activities, social and knowledge networks, and cultural behaviours.

- Core process knowledge. What processes fuel this company's competitive edge? In other words, which processes make this company unique?

- Industry knowledge. What forces, markets and models characterize this industry? Which parties or industries are traditional or emerging buyers and sellers? How does regulation affect this industry? Which industries does this industry resemble? (Gartner 2005)

The question then is: how can professional education in ICT relate to these issues?

\section{ICT Professionalism}

Most professionals in the field of Information and Communications Technology (ICT) are well used to change and accept the need for keeping up-to-date with new technologies, new products, new processes and new concepts (Tatnall 2007). Not all, however, have realised a need to keep up to date with issues of professionalism, and the Australian Computer Society (ACS) sees this as a sign of an immature profession (Parakala 2008). The ACS National President argues that professionalism should be seen as a way of maximising quality and reducing risks. "With technology underpinning so much of our lives today the need to raise the bar for professionalism has never been greater." (Parakala 2008 :5) He goes on to note that:

"This is why the ACS believes that Australia's future prosperity is closely tied to ICT professionalism, which is all about delivering products and services that are trustworthy, as distinct from trusted." (Parakala 2008 :5)

The ACS website (Australian Computer Society 2008) defines professionalism as practised by the ACS to mean that:

- An individual's qualifications have been objectively assessed and verified;

- They are required to continually update their knowledge and are provided with appropriate opportunities to do so; 
- They have access to other experts in their specialist field and can both share and acquire knowledge and access to skills through networking;

- Ethical, social and legal implications of technology are actively considered when designing and applying technology systems and processes;

- Members recognise the value of contributing to their profession and developing young professionals through mentoring; and

- They are subject to strict disciplinary measures if they perform unethically or otherwise unprofessionally.

One of the ways that computing professional societies around the world typically promote the development of professional responsibility in their members is to have a Code of Ethics to which their members must subscribe (IEEE 2006; ACM 2007; ACS 2008) ${ }^{2}$. The purpose of these codes is to promote quality, integrity, honesty and lifelong learning. Another way that these societies promote professionalism is in offering and supporting lifelong learning in both ICT knowledge areas and professional issues.

\section{The ICT Profession and the ACS Body of Knowledge}

The Professional Standards Board of the Australian Computer Society recently released a working paper on 'The ICT Profession and the ICT Body of Knowledge' (Gregor, von Konsky, Hart and Wilson 2008). The idea is that universities, in designing their ICT courses, make use of this Body of Knowledge. The document advocates an approach focusing on "the development of professionals, rather than taking a strict bottom-up 'curriculum-driven' approach" (Gregor, von Konsky et al. 2008 : 7). As well as generic ICT graduate skill sets and complementary knowledge of the study domain, the document proposes that the core body of knowledge be split into two areas (Gregor, von Konsky et al. 2008):

1. An ICT Knowledge Area comprising:

a. Problem solving using modelling and abstraction

b. Hardware and software fundamentals

c. Data and information management

d. Networking

e. Programming fundamentals

f. Human-computer interaction

g. System development and acquisition

h. ICT project management

2. A Professional Knowledge Area that examined:
a. Ethics
b. Professionalism
c. Governance and organisational issues
d. Teamwork concepts and issues
e. Communication
f. Societal issues

The document argues that content in the professionalism area should cover basic concepts of professionalism such as expertise, certification, competence, autonomy, excellence, reflection, responsibility and accountability. Professional undergraduate education in ICT could thus be considered to have two aspects:

- Technical education in how to use ICT in their future job, and

- Education in how to act as an ICT professional.

2 See Appendix A, B and C. 


\section{Professional Practice in the ACM Computing Curriculum}

In a chapter on Professional Practice, the final draft of the new curriculum document: IT-2008 - the Information Technology Volume of the ACM Computing Curriculum (ACM 2008) begins by noting that:

"As the field of computing continues to change, an unprecedented opportunity exists to make professional practice a seamless part of the curriculum in Information Technology and other computing disciplines." (ACM 2008)

This document then identifies four ways in which this professionalism can be incorporated in undergraduate IT programs:

- Senior capstone courses

- Professionalism, ethics and law courses

- Practicum/internship/co-op programs

- Team-based implementation courses.

\section{Professionalism and Undergraduate University Education}

This is an interesting wish list, but is it practical? We looked at a typical Australian University to see if these programs were implemented and, if so, what form they might take. At RMIT University an undergraduate program is offered in 'Business Information Systems'.

"This program is designed to meet the growing needs of industry for a new type of Information Technology professional; in particular, graduates who possess a sound business background combined with the ability to develop and manage business information systems in a wide range of business, government and non-government setting. "(RMIT University 2008a)

On studying this document it seems that the courses 'Professional Practice for Information Systems', 'BIS Work Integrated Learning' and 'Business Information Systems Capstone Project' are the vehicles for delivering the professionalism component of the degree. The first of these, conducted before the student undertake work experience, notes that:

“... particular attention will be given to skills development in the areas of project management, contract administration and tender evaluation, organisational, cultural and ethical issues, and human resource management" (RMIT University 2008c)

Students then complete a year of paid employment, whilst simultaneously undertaking the course 'BIS Work Integrated Learning' consisting of evening seminars designed to "integrate students work experiences with previous and current learning." (RMIT University 2008d) The last compulsory final year course is then Business Information Systems Capstone Project:

"This capstone course will not introduce any new technical curricula but seeks to lead students, working in groups, to analyse, design, and build a business information systems component under normal business conditions." (RMIT University 2008b)

The program containing these courses is one that has not decreased in popularity amongst high School leavers despite a general downturn in computing-related course in Australia. One can conclude that it is both possible to include professionalism in undergraduate degrees, but that this does not diminish the attractiveness of the degree.

Information Systems students at Victoria University (VU) also have the option of undertaking a year of work experience, but unlike RMIT, at VU this is optional. All business undergraduate courses at VU (including those in Information Systems) now contain three new Professional Development subjects that are designed to cover the three broad areas of: business knowledge, personal attributes and professional skills. Amongst other things: 
"The emerging political, social, economic, technological and ethical issues impacting on business will be identified and investigated." (Victoria University - Faculty of Business and Law 2008)

\section{ICT Professionals and Lifelong Learning}

Most world governments had now recognised the importance of support for lifelong learning (Davey and Tatnall 2007), and the European Commission suggests that lifelong learning should encompass the whole spectrum of formal, non-formal and informal learning from pre-school to post-retirement (European Commission 2001). It define lifelong learning as "Any learning activity undertaken throughout life, with the aim of improving knowledge, skills and competences within a personal, civic, social and/or employment-related perspective." (European Commission 2001) In 1970 UNESCO adopted Lifelong Learning as a master concept (Tight 1998) and in 1998 the British Education Secretary, David Blunkett (1998), noted that: "In the $21^{\text {st }}$ century learning at different stages in life will be essential as human capital becomes to the information revolution what fixed capital was to the industrial revolution." At a recent IFIP conference on 'ICT and Real-Life Learning', Mike Kendall (2005) took the position that real-life learning and lifelong learning are, in effect, the same activity with different names. He went on to argue that lifelong learning will continue to gain in prominence, and explored the relationship between lifelong learning and informal learning styles as well as how this relates to vocational and professional education.

The Australian Computer Society (ACS) states that: "Professionals have an obligation to themselves and the ICT community to maintain their skills and knowledge through ongoing professional development" (Australian Computer Society 2007a), and has developed a Practicing Computer Professional (PCP) program that: "enables ACS members to differentiate themselves from other members of the ICT community by showing that they have undertaken this continuing professional development" (Australian Computer Society 2007a). To achieve PCP status an ACS member must undertake a minimum of thirty hours of structured professional development every year which could include: "lectures, seminars, formal education, discussion groups and special interest groups, writing and delivering papers and conducting research" (Australian Computer Society 2007a). Learning for ICT professionals can thus be classified as including training in a specific product, process or concept (perhaps on-line); professional reading; attendance at a seminar or conference; undertake some form of research; or undertaking a higher degree or diploma.

There are a number of ways in which current ICT professionals can continue their education and engage in some form of lifelong learning. These include training courses in some new product, attending industry conferences, attending relevant seminars and presentations, professional reading, and undertaking some form of postgraduate study.

While most ICT professionals engage in some form of Lifelong Learning, they still need to decide what learning to do (Tatnall 2007). In some cases they have no choice in this: they must undertake the training courses their employer requires, but in other cases they have to decide which product, technology, process or concept to learn about next.

\section{Industry Training Courses}

There is a real need for most ICT professionals, from time to time, to attend various product, concept and technology training courses. Some courses of this type are often offered by the industry itself in the form of product training by the companies that manufacture or market new products. There are a number of training companies that specialise in offering training leading to certificates such as: Microsoft Certified Systems Engineer, Microsoft Certified Application Developer, Cisco Certified Network Associate, Oracle9i Certified Associate, Professional and Master and so on (About.com 2008). Other courses are offered by the professional societies while some are also offered by institutions of further education - in Australia these are called Institutes of Technical and Further Education (TAFE). Most of these courses, however, concentrate on the technical side of training and do not go far, if at all, into professional matters such as ethics, honesty and integrity. 


\section{ICT Professionals and Postgraduate Studies}

One way to engage in lifelong learning is to enrol in another university course at some time after completing an initial qualification. One group of people who undertake postgraduate studies is middle aged ICT workers who typically began working in ICT when there was little need for a formal qualification. As most new entrants to the professional now have degrees in information systems or computer science, they have felt the need to acquire some form of formal qualification in order to justify their current position or to gain promotion. Current ICT professionals with some form of initial formal qualification in ICT sufficient to qualify them for ACS membership often want to undertake a higher degree to enhance their promotion prospects or to gain extra knowledge in another area of ICT.

There is a wide range of available postgraduate ICT courses that cover topics from IT management, electronic commerce and business intelligence to enterprise resource planning. In most cases, current ICT professionals undertaking such courses do so either to gain a higher qualification to increase their future employment prospects, or simply to learn about a new area.

\section{University ICT Academics}

One group of ICT professionals who do, typically, engage in some form of lifelong learning is university ICT academics. An Australian study on lifelong learning by ICT academics (Davey and Tatnall 2007) involved interviews with thirty six academics from sixteen universities across eleven countries. Each of the academics interviewed was fully qualified (had completed a $\mathrm{PhD}$ or equivalent) and so did not need to do any further study for employment or tenure purposes. The study found that academics do not value formal learning as much as they do informal learning, and that the most valued informal learning methods were structured ways for academics to interact with other academics. The study showed that in particular, many IS academics value academic conferences most highly and think that their research and teaching benefit greatly by the currency of the ideas presented and the interactions that take place at these conferences (Davey and Tatnall 2007).

\section{Conclusion}

ICT professionals typically see a need to keep up-to-date with new developments in their profession, and to undertake on-going learning in technical matters. Not all, however, realise the need to keep up with other issues in professionalism and ethics. In this article we have considered the meaning of ICT professionalism and its importance, particularly from an Australian perspective. We have also looked at ways in which both undergraduate education and lifelong learning can be used to improve ICT professionalism.

Most universities in Australia submit their ICT courses for accreditation to the Australian Computer Society. As the ACS requires such courses to contain a component dealing with professionalism to be included, most Australian ICT courses now contain such a component, or are in the process of adding one. This means that future ICT professionals in this country will have a better grounding than their predecessors in what is means to be a professional.

\section{References}

About.com. (2008). "Computer Certification.” from http://certification.about.com/od/certifications/All Certifications.htm.

ACM. (2007). “ACM Code of Ethics and Professional Conduct." Retrieved October 2008, from http://www.acm.org/about/code-of-ethics.

ACM (2008). IT-2008 ACM Computing Curriculum, Information Technology volume. New York, Association for Computing Machinery.

ACS. (2008). "Australian Computer Society Code of Ethics." Retrieved October 2008, from http://www.acs.org.au/index.cfm?action=show\&conID=coe\#top.

Arnold, F. D., Bernardi, R. A., Neidermeyer, P. E. and Schmee, J. (2005). "Personal versus professional ethics in confidentiality decisions: an exploratory study in Western Europe." Business Ethics: A European Review 14(3). 
Australian Computer Society. (2007a). “Computer Professional Program.” Retrieved May 2007, from http://www.acs.org.au.

Australian Computer Society. (2007b). "ICT Professionals Shaping Our Future." Retrieved November 2007, from http://www.acs.org.au/.

Australian Computer Society. (2008). "Practising professionalism " Retrieved October 2008, from https://www.acs.org.au/index.cfm?action=show\&conID=200806131436156192.

Badaracco, J. L. (2003). We Don't Need Another Hero. Harvard Business Review on Corporate Ethics. Boston, Harvard Business School Press: 1-17.

Blunkett, D. (1998). Opportunities to Live and Learn Times Higher Education Supplement. London. 27 Feb 1998.

Braendle, U. C. and Noll, J. (2005). "A Fig Leaf for the Naked Corporation.” Journal of Management and Governance(9): $79-99$.

Brammer, S., Williams, G. and Zinkin, J. (2007). "Religion and Attitudes to Corporate Social Responsibility in a Large Cross-Country Sample " Journal of Business Ethics 71(3): 229-243.

Brenner, S. N. (1992). "Ethics Programs and Their Dimensions." Journal of Business Ethics 11: 391 399

Child, J. and Rodrigues, S. (2003). “The International Crisis of Confidence in Corporations.” Journal of Management and Governance 7: 233-240.

Clarke, T. (2007). International Corporate Governance: A Comparative Approach, Routledge.

Davey, B. and Tatnall, A. (2007). "The Lifelong Learning Iceberg of Information Systems Academics - a Study of On-Going Formal and Informal Learning by Academics.” Journal of Information Technology Education 6: 241-248.

Davey, B. and Tatnall, A. (2008). Where Will Professional Software Engineering Education Go Next? Learning to Live in the Knowledge Society. Kendall, M. and Samways, B. New York, Springer: 185-192.

De George, R. T. (1987). "The Status of Business Ethics Past and Future.” Journal of Business Ethics 6: $201-211$.

De George, R. T. (2006). "An American perspective on corporate social responsibility and the tenuous relevance of Jacques Derrida.” Business Ethics: A European Review 17(1): 74-86.

Department of Communication; Information Technology and the Arts (2006). Building Australian ICT Skills: Report of the ICT Skills Foresighting Working Group. Barton, ACT, Australian Government, Department of Communication; Information Technology and the Arts

Donaldson, T. and Preston, L. (1995). "The stakeholder theory of the modern corporation: Concepts, evidence and implications." Academy of Management Review 20: 65-91.

Estes, R. (1996). Tyranny of the Bottom Line. San Francisco, CA, Berrett-Koehler Publishers.

European Commission (2001). Making a European Area of Lifelong Learning a Reality. Brussels, Commission of the European Communities.

Fernando, M., Dharmage, S. and Almeida, S. (2007). "Ethical Ideologies of Senior Australian Managers: An Empirical Study.” Journal of Business Ethics 82: 145-155.

Ford Motor Company. (2009). "Dearborn Truck Plant is a Model of Flexible and Sustainable Manufacturing." Retrieved 26 June, 2009, from www.ford.com.

Forsyth, D. R. (1980). “A Taxonomy of Ethical Ideologies.” Journal of Personality and Social Psychology 39(1): 175-184.

Fort, T. L. (1997). "Religion and Business Ethics: The Lessons from Political Morality “ Journal of Business Ethics 16(3): 263-273.

Furneaux, B. (2008, This page was last modified 16:02, 28 January 2008). "Stakeholder Theory." Retrieved 14 September, 2008.

Gartner (2005). The IT Professional Outlook: Where Will We Go From Here? Orlando, Florida, Gartner.

Gregor, S., von Konsky, B. R., Hart, R. and Wilson, D. (2008). "The ICT Profession and the ICT Body of Knowledge (version 4.0)." Retrieved October 2008, from https://www.acs.org.au/index.cfm?action=show\&conID=200806131436156192.

Hubbard, R. L. (2007). Introduction to Scientology Ethics. Copenhagen, Denmark, New Era Publications. 
Hunt, S. D. and Vitell, S. (1993). The General Theory of Marketing Ethics: A Retrospective and Revision. Ethics in Marketing. Smith, N. C. and Quelch, J. A. Illinois, Irwin, Homewood.

IEEE. (2006). "IEEE Code of Ethics." Retrieved October 2008, from http://www.ieee.org/portal/pages/iportals/aboutus/ethics/code.html.

Illes, J. J. (2007). "Responding Destructively in Leadership Situations: The Role of Personal Values and Problem Construction." Journal of Business Ethics 82: 251-272.

Jennings, M. M. (2006). The Seven Signs of Ethical Collapse. New York, St. Martin's Press.

Kendall, M. (2005). Exploring the Role Of Informal Learning in Real-Life Learning. Information and Communication Technologies and Real-Life Learning - New Education for the Knowledge Society. van Weert, T. and Tatnall, A. New York, Springer/IFIP: 189-196.

Kochan, T. A. (2003). "Restoring Trust in American Corporations: Addressing the Root Cause." Journal of Management and Governance(7): 223-231.

Longenecker, J. G., McKinney, J. A. and Moore, C. W. (2004). "Religious Intensity, Evangelical Christianity, and Business Ethics: An Empirical Study." Journal of Business Ethics 55: 373 386.

McMurtry, J. (2002). "Why the Protestors Are Against Corporate Globalization.” Journal of Business Ethics 40: 201-205.

Moody, K. (2007). US Labor in Trouble and Transition. The Failure of Reform From Above, the Promise of Revival From Below. London, Verso.

Noreen, E. (1988). "The economics of ethics: A new perspective on agency theory." Accounting, Organizations and Society 13(4): 359-370.

Paine, L. S. (1994). "Managing for Organizational Integrity.” Harvard Business Review(Mar - Apr): $106-117$.

Parakala, K. (2008). “Practising Professionalism.” Information Age (June/July): 5.

Parboteeah, K. P., Hoegl, M. and Cullen, J. B. (2008). "Ethics and Religion: An Empirical Test of a Multidimensional Model " Journal of Business Ethics 80(2): 387-398.

Quinn, J. J. (1997). "Personal Ethics and Business Ethics: The Ethical Attitudes of Owner/Managers of Small Business." Journal of Business Ethics(16): 119 - 127.

Reynolds, M. (2009). “Garbage Warrior.” Retrieved May, 2009, from http://www.garbagewarrior.com/index.php.

Ritchie, F. (1996). Finishing First With Ethics: Bringing good business principles and sound ethics together for greater profits and a better future. Sydney, Business \& Professional Publishing.

RMIT University (2008a). Business Information Systems degree 2009. Melbourne, RMIT University.

RMIT University (2008b). Course Guide: Business Information Systems Capstone Project. Melbourne, RMIT University.

RMIT University (2008c). Course Guide: Professional Practice for Information Systems. Melbourne, RMIT University.

RMIT University (2008d). We produce work ready graduates. Melbourne, RMIT University.

Rogers, W. and Gago, S. (2004). "Stakeholder Influence on Corporate Strategies Over Time." Journal of Business Ethics 52: 349-363.

Rose, J. M. (2007). "Corporate Directors and Social Responsibility: Ethics versus Shareholder Value." Journal of Business Ethics 73: 319-331.

Schwartz, M. (2001). "The Nature of the Relationship between Corporate Codes of Ethics and Behaviour." Journal of Business Ethics 32: 247-262.

Schwartz, M. S. (2006). "God as a Managerial Stakeholder?” Journal of Business Ethics 66(2-3).

Singhapakdi, A., Marta, J. K., Rallapalli, K. C. and Rao, C. P. (2000). "Toward an Understanding of Religiousness and Marketing Ethics: An Empirical Study “ Journal of Business Ethics 27(4): 305-319

Stead, E. W., Worrell, D. L. and Stead, G. J. (1990). “An Integrative Model for Understanding and Managing Ethical Behavior in Business Organizations." Journal of Business Ethics 9: 233242.

Svensson, G. and Wood, G. (2007). “A Model of Business Ethics.” Journal of Business Ethics 77: 303-322. 
Tatnall, A. (2007). Innovation, Lifelong Learning and the ICT Professional. Education, Training and Lifelong Learning. Tatnall, A., Thompson, J. B. and Edwards, H. Laxenburg, Austria, IFIP: 92-101.

The Religious Society of Friends. (2009). "English Quakers Establish Chocolate Businesses." Retrieved 24 June, 2009, from www.quakerinfo.com.

Thompson, J. B. (2006). The Future of ICT Education in the UK (Personnal Communication). Newcastle, UK.

Tight, M. (1998). "Lifelong Learning: Opportunity or Compulsion.” British Journal of Educational Studies 46(3): 251-263.

Turner, C. (2009). Australian Commercial Law. Sydney, Thomson Reuters.

Victoria University - Faculty of Business and Law (2008). Faculty of Business and Law Handbook 2008. Melbourne, Victoria University.

Waddock, S. (2005). "Hollow Men and Women at the Helm... Hollow Accounting Ethics?" Issues in Accounting Education 20: 145 - 150.

Waring, P. and Edwards, T. (2008). "Socially Responsible Investment: Explaining its Uneven Development and Human Resource Management Consequences." Socially Responsible Investment 16(3): 135-145.

Weaver, G. R., Trevino, L. K. and Cochran, P. L. (1999). "Corporate Ethics Practices in the Mid 1990's: An Empirical Study of the Fortune 1000 “ Journal of Business Ethics 18: 283-294.

Whetstone, J. T. (2002). "Personalism and moral leadership: the servant leader with a transforming vision." Business Ethics: A European Review 11(4). 


\section{Appendix A: Australian Computer Society (ACS) Code of Ethics}

\section{A Requirement}

An essential characteristic of a profession is the need for its members to abide by a Code of Ethics. The Society requires its members to subscribe to a set of values and ideals which uphold and advance the honour, dignity and effectiveness of the profession of information technology. The code is part of the Society's Regulations and the numbering sequence has been maintained.

\section{Code of Ethics}

4.1 To uphold and advance the honour, dignity and effectiveness of the profession of information technology and in keeping with high standards of competence and ethical conduct, a member must:

(a) be honest, forthright and impartial, and

(b) loyally serve the community, and

(c) strive to increase the competence and prestige of the profession, and

(d) use special knowledge and skill for the advancement of human welfare.

4.2 The personal commitments set out in NR4.3 and NR4.4 bind each member with regard to that member's professional conduct.

4.3 Values and Ideals

I must act with professional responsibility and integrity in my dealings with the community and clients, employers, employees and students. I acknowledge:

4.3.1 Priorities

I must place the interests of the community above those of personal or sectional interests.

4.3.2 Competence

I must work competently and diligently for my clients and employers.

4.3.3 Honesty

I must be honest in my representation of skills, knowledge, services and products.

4.3.4 Social Implications

I must strive to enhance the quality of life of those affected by my work.

4.3.5 Professional Development

I must enhance my own professional development, and that of my colleagues, employees and students.

4.3.6 Information Technology Profession

I must enhance the integrity of the information technology profession and the respect of its members for each other.

\subsection{Standards of Conduct}

The standards of conduct set out in these National Regulations explain how the Code of Ethics applies to a member's professional work. The list of standards is not necessarily exhaustive and should not be read as definitively demarking the acceptable from the unacceptable in professional conduct in all practical situations faced by a member. The intention of the standards of conduct is to illustrate, and to explain in more detail, the meaning of the Code of Ethics in terms of specific behaviour. The fact that a member engages in, or does not engage in, these standards does not of itself guarantee that a member is acting ethically, or unethically, as applicable. A member is expected to take into account the spirit of the Code of Ethics in order to resolve ambiguous or contentious issues concerning ethical conduct.

\subsection{Priorities}

In accordance with NR4.3.1:

4.5.1 I must endeavour to preserve continuity of information technology services and information flow in my care.

4.5.2 I must endeavour to preserve the integrity and security of the information of others.

4.5.3 I must respect the proprietary nature of the information of others.

4.5.4 I must endeavour to preserve the confidentiality of the information of others.

4.5.5 I must advise my client or employer of any potential conflicts of interest between my assignment and legal or other accepted community requirements.

4.5.6 I must advise my clients and employers as soon as possible of any conflicts of interest or conscientious objections which face me in connection with my work.

\subsection{Competence}

In accordance with NR4.3.2:

4.6.1 I must endeavour to provide products and services which match the operational and financial needs of my clients and employers

4.6.2 I must give value for money in the services and products I supply.

4.6.3 I must make myself aware of relevant standards, and act accordingly.

4.6.4 I must respect and protect my clients' and employers' proprietary interests.

4.6.5 I must accept responsibility for my work.

4.6.6 I must advise my clients and employers when I believe a proposed project is not in their best interest.

4.6.7 I must go beyond my brief, if necessary, in order to act professionally.

\subsection{Honesty}

In accordance with NR4.3.3:

4.7.1 I must not knowingly mislead a client or potential client as to the suitability of a product or service.

4.7.2 I must not misrepresent my skills or knowledge.

4.7.3 I must give opinions which are as far as possible unbiased and objective.

4.7.4 I must give realistic estimates for projects under my control.

4.7.5 I must qualify professional opinions which I know are based on limited knowledge or experience. 
4.7.6 I must give credit for work done by others where credit is due.

\subsection{Social Implications}

In accordance with NR4.3.4:

4.8.1 I must protect and promote the health and safety of those affected by my work.

4.8.2 I must consider and respect people's privacy which might be affected by my work.

4.8.3 I must respect my employees and refrain from treating them unfairly.

4.8.4 I must endeavour to understand, and give due regard to, the perceptions of those affected by my work.

4.8.5 I must attempt to increase the feelings of personal satisfaction, competence, and control of those affected by my work.

4.8.6 I must not require, or attempt to influence, any person to take any action which would involve a breach of the Code of Ethics.

\subsection{Professional Development}

In accordance with NR4.3.5:

4.9.1 I must continue to upgrade my knowledge and skills.

4.9.2 I must increase my awareness of issues affecting the information technology profession and its relationship with the community.

4.9.3 I must encourage my colleagues, employees and students to continue their own professional development.

\subsection{Information Technology Profession}

In accordance with NR4.3.6:

4.10.1 I must respect, and seek when necessary, the professional opinions of colleagues in their areas of competence.

4.10.2 I must not knowingly engage in, or be associated with, dishonest or fraudulent practices.

4.10.3 I must not attempt to enhance my own reputation at the expense of another's reputation.

4.10.4 I must co-operate in advancing information processing by communication with other professionals, students and the public, and by contributing to the efforts of professional and scientific societies and schools.

4.10.5 I must distance myself professionally from someone whose membership of the Society has been terminated because of unethical behaviour or unsatisfactory conduct.

4.10.6 I must take appropriate action if I discover a member, or a person who could potentially be a member, of the Society engaging in unethical behaviour.

4.10.7 I must seek advice from the Society when faced with an ethical dilemma I am unable to resolve by myself.

4.10.8 I must do what I can to ensure that the corporate actions of the Society are in accordance with this Code of Ethics.

4.10.9 I acknowledge my debt to the computing profession and in return must protect and promote professionalism in information technology

http://www.acs.org.au/index.cfm?action=show\&conID $=200509022322219027$ 


\title{
Appendix B: Software Engineering Code of Ethics and Professional Practice of the Institution for Electrical and Electronic Engineers (IEEE)
}

\author{
Software Engineering Code of Ethics and Professional Practice - short version \\ "The time is right to get serious about this. As software becomes increasingly dominant in the IT industry, and, indeed, in \\ everything else, there is an obvious need for a professional-level recognition. Far too much is placed on particular credentials \\ for specific products or applications without regard to the bigger picture. The result is poorly engineered software projects."
}

(Version 5.2) as recommended by the IEEE-CS/ACM Joint Task Force on Software Engineering Ethics and Professional Practices and Jointly approved by the ACM and the IEEE-CS as the standard for teaching and practicing software engineering.

\section{Preamble}

The short version of the code summarizes aspirations at a high level of the abstraction; the clauses that are included in the full version give examples and details of how these aspirations change the way we act as software engineering professionals. Without the aspirations, the details can become legalistic and tedious; without the details, the aspirations can become high sounding but empty; together, the aspirations and the details form a cohesive code.

Software engineers shall commit themselves to making the analysis, specification, design, development, testing and maintenance of software a beneficial and respected profession. In accordance with their commitment to the health, safety and welfare of the public, software engineers shall adhere to the following Eight Principles:

1. PUBLIC - Software engineers shall act consistently with the public interest.

2. CLIENT AND EMPLOYER - Software engineers shall act in a manner that is in the best interests of their client and employer consistent with the public interest.

3. PRODUCT - Software engineers shall ensure that their products and related modifications meet the highest professional standards possible.

4. JUDGMENT - Software engineers shall maintain integrity and independence in their professional judgment.

5. MANAGEMENT - Software engineering managers and leaders shall subscribe to and promote an ethical approach to the management of software development and maintenance.

6. PROFESSION - Software engineers shall advance the integrity and reputation of the profession consistent with the public interest.

7. COLLEAGUES - Software engineers shall be fair to and supportive of their colleagues.

8. SELF - Software engineers shall participate in lifelong learning regarding the practice of their profession and shall promote an ethical approach to the practice of the profession.

This Code was developed by the IEEE-CS/ACM joint task force on Software Engineering Ethics and Professional Practices (SEEPP): Executive Committee: Donald Gotterbarn (Chair), Keith Miller and Simon Rogerson; Members: Steve Barber, Peter Barnes, Ilene Burnstein, Michael Davis, Amr El-Kadi, N. Ben Fairweather, Milton Fulghum, N. Jayaram, Tom Jewett, Mark Kanko, Ernie Kallman, Duncan Langford, Joyce Currie Little, Ed Mechler, Manuel J. Norman, Douglas Phillips, Peter Ron Prinzivalli, Patrick Sullivan, John Weckert, Vivian Weil, S. Weisband and Laurie Honour Werth.

This Code may be published without permission as long as it is not changed in any way and it carries the copyright notice.

Copyright 1999 by the Institute for Electrical and Electronics Engineers, Inc. and the Association for Computing Machinery, Inc.

http://www.computer.org/portal/site/ieeecs/menuitem.c5efb9b8ade9096b8a9ca0108bcd45f3/index.jsp?\&pName=ieeecs level $1 \&$ path $=$ ieeecs/content\&file=ethics $\mathrm{xml} \& \mathrm{xsl}=$ generic $\mathrm{xsl} \&$ 


\title{
Appendix C: Code of Ethics of the Association for Computing Machinery (ACM)
}

\author{
1. General Moral Imperatives \\ As an ACM member I will ...
}

\subsection{Contribute to society and human well-being}

This principle concerning the quality of life of all people affirms an obligation to protect fundamental human rights and to respect the diversity of all cultures. An essential aim of computing professionals is to minimize negative consequences of computing systems, including threats to health and safety. When designing or implementing systems, computing professionals must attempt to ensure that the products of their efforts will be used in socially responsible ways, will meet social needs, and will avoid harmful effects to health and welfare.

In addition to a safe social environment, human well-being includes a safe natural environment. Therefore, computing professionals who design and develop systems must be alert to, and make others aware of, any potential damage to the local or global environment.

\subsection{Avoid harm to others}

"Harm" means injury or negative consequences, such as undesirable loss of information, loss of property, property damage, or unwanted environmental impacts. This principle prohibits use of computing technology in ways that result in harm to any of the following: users, the general public, employees, employers. Harmful actions include intentional destruction or modification of files and programs leading to serious loss of resources or unnecessary expenditure of human resources such as the time and effort required to purge systems of "computer viruses."

Well-intended actions, including those that accomplish assigned duties, may lead to harm unexpectedly. In such an event the responsible person or persons are obligated to undo or mitigate the negative consequences as much as possible. One way to avoid unintentional harm is to carefully consider potential impacts on all those affected by decisions made during design and implementation.

To minimize the possibility of indirectly harming others, computing professionals must minimize malfunctions by following generally accepted standards for system design and testing. Furthermore, it is often necessary to assess the social consequences of systems to project the likelihood of any serious harm to others. If system features are misrepresented to users, coworkers, or supervisors, the individual computing professional is responsible for any resulting injury.

In the work environment the computing professional has the additional obligation to report any signs of system dangers that might result in serious personal or social damage. If one's superiors do not act to curtail or mitigate such dangers, it may be necessary to "blow the whistle" to help correct the problem or reduce the risk. However, capricious or misguided reporting of violations can, itself, be harmful. Before reporting violations, all relevant aspects of the incident must be thoroughly assessed. In particular, the assessment of risk and responsibility must be credible. It is suggested that advice be sought from other computing professionals. See principle 2.5 regarding thorough evaluations.

\subsection{Be honest and trustworthy}

Honesty is an essential component of trust. Without trust an organization cannot function effectively. The honest computing professional will not make deliberately false or deceptive claims about a system or system design, but will inste ad provide full disclosure of all pertinent system limitations and problems.

A computer professional has a duty to be honest about his or her own qualifications, and about any circumstances that might lead to conflicts of interest.

Membership in volunteer organizations such as ACM may at times place individuals in situations where their statements or actions could be interpreted as carrying the "weight" of a larger group of professionals. An ACM member will exercise care to not misrepresent ACM or positions and policies of ACM or any ACM units.

\subsection{Be fair and take action not to discriminate}

The values of equality, tolerance, respect for others, and the principles of equal justice govern this imperative. Discrimination on the basis of race, sex, religion, age, disability, national origin, or other such factors is an explicit violation of ACM policy and will not be tolerated.

Inequities between different groups of people may result from the use or misuse of information and technology. In a fair society,all individuals would have equal opportunity to participate in, or benefit from, the use of computer resources regardless of race, sex, religion, age, disability, national origin or other such similar factors. However, these ideals do not justify unauthorized use of computer resources nor do they provide an adequate basis for violation of any other ethical imperatives of this code.

\subsection{Honor property rights including copyrights and patent}

Violation of copyrights, patents, trade secrets and the terms of license agreements is prohibited by law in most circumstances. Even when software is not so protected, such violations are contrary to professional behavior. Copies of software should be made only with proper authorization. Unauthorized duplication of materials must not be condoned. 


\subsection{Give proper credit for intellectual property}

Computing professionals are obligated to protect the integrity of intellectual property. Specifically, one must not take credit for other's ideas or work, even in cases where the work has not been explicitly protected by copyright, patent, etc.

\subsection{Respect the privacy of others}

Computing and communication technology enables the collection and exchange of personal information on a scale unprecedented in the history of civilization. Thus there is increased potential for violating the privacy of individuals and groups. It is the responsibility of professionals to maintain the privacy and integrity of data describing individuals. This includes taking precautions to ensure the accuracy of data, as well as protecting it from unauthorized access or accidental disclosure to inappropriate individuals. Furthermore, procedures must be established to allow individuals to review their records and correct inaccuracies.

This imperative implies that only the necessary amount of personal information be collected in a system, that retention and disposal periods for that information be clearly defined and enforced, and that personal information gathered for a specific purpose not be used for other purposes without consent of the individual(s). These principles apply to electronic communications, including electronic mail, and prohibit procedures that capture or monitor electronic user data, including messages, without the permission of users or bona fide authorization related to system operation and maintenance. User data observed during the normal duties of system operation and maintenance must be treated with strictest confidentiality, except in cases where it is evidence for the violation of law, organizational regulations, or this Code. In these cases, the nature or contents of that information must be disclosed only to proper authorities.

\subsection{Honor confidentiality}

The principle of honesty extends to issues of confidentiality of information whenever one has made an explicit promise to honor confidentiality or, implicitly, when private information not directly related to the performance of one's duties becomes available. The ethical concern is to respect all obligations of confidentiality to employers, clients, and users unless discharged from such obligations by requirements of the law or other principles of this Code.

\section{More Specific Professional Responsibilities}

As an ACM computing professional I will ...

\subsection{Strive to achieve the highest quality, effectiveness and dignity in both the process and products of professional work}

Excellence is perhaps the most important obligation of a professional. The computing professional must strive to achieve quality and to be cognizant of the serious negative consequences that may result from poor quality in a system.

\subsection{Acquire and maintain professional competence}

Excellence depends on individuals who take responsibility for acquiring and maintaining professional competence. A professional must participate in setting standards for appropriate levels of competence, and strive to achieve those standards. Upgrading technical knowledge and competence can be achieved in several ways: doing independent study; attending seminars, conferences, or courses; and being involved in professional organizations.

\subsection{Know and respect existing laws pertaining to professional work}

ACM members must obey existing local, state, province, national, and international laws unless there is a compelling ethical basis not to do so. Policies and procedures of the organizations in which one participates must also be obeyed. But compliance must be balanced with the recognition that sometimes existing laws and rules may be immoral or inappropriate and, therefore, must be challenged. Violation of a law or regulation may be ethical when that law or rule has inadequate moral basis or when it conflicts with another law judged to be more important. If one decides to violate a law or rule because it is viewed as unethical, or for any other reason, one must fully accept responsibility for one's actions and for the consequences.

\subsection{Accept and provide appropriate professional review}

Quality professional work, especially in the computing profession, depends on professional reviewing and critiquing. Whenever appropriate, individual members should seek and utilize peer review as well as provide critical review of the work of others.

\subsection{Give comprehensive and thorough evaluations of computer systems and their impacts, including analysis of possible risks}

Computer professionals must strive to be perceptive, thorough, and objective when evaluating, recommending, and presenting system descriptions and alternatives. Computer professionals are in a position of special trust, and therefore have a special responsibility to provide objective, credible evaluations to employers, clients, users, and the public. When providing evaluations the professional must also identify any relevant conflicts of interest, as stated in imperative 1.3.

As noted in the discussion of principle 1.2 on avoiding harm, any signs of danger from systems must be reported to those who have opportunity and/or responsibility to resolve them. See the guidelines for imperative 1.2 for more details concerning harm, including the reporting of professional violations. 


\subsection{Honor contracts, agreements, and assigned responsibilities}

Honoring one's commitments is a matter of integrity and honesty. For the computer professional this includes ensuring that system elements perform as intended. Also, when one contracts for work with another party, one has an obligation to keep that party properly informed about progress toward completing that work.

A computing professional has a responsibility to request a change in any assignment that he or she feels cannot be completed as defined. Only after serious consideration and with full disclosure of risks and concerns to the employer or client, should one accept the assignment. The major underlying principle here is the obligation to accept personal accountability for professional work. On some occasions other ethical principles may take greater priority.

A judgment that a specific assignment should not be performed may not be accepted. Having clearly identified one's concerns and reasons for that judgment, but failing to procure a change in that assignment, one may yet be obligated, by contract or by law, to proceed as directed. The computing professional's ethical judgment should be the final guide in deciding whether or not to proceed. Regardless of the decision, one must accept the responsibility for the consequences.

However, performing assignments "against one's own judgment" does not relieve the professional of responsibility for any negative consequences.

\subsection{Improve public understanding of computing and its consequences}

Computing professionals have a responsibility to share technical knowledge with the public by encouraging understanding of computing, including the impacts of computer systems and their limitations. This imperative implies an obligation to counter any false views related to computing.

\subsection{Access computing and communication resources only when authorized to do so}

Theft or destruction of tangible and electronic property is prohibited by imperative 1.2 - "Avoid harm to others." Trespassing and unauthorized use of a computer or communication system is addressed by this imperative. Trespassing includes accessing communication networks and computer systems, or accounts and/or files associated with those systems, without explicit authorization to do so. Individuals and organizations have the right to restrict access to their systems so long as they do not violate the discrimination principle (see 1.4). No one should enter or use another's computer system, software, or data files without permission. One must always have appropriate approval before using system resources, including communication ports, file space, other system peripherals, and computer time.

\section{Organizational Leadership Imperatives}

As an ACM member and an organizational leader, I will ...

BACKGROUND NOTE: This section draws extensively from the draft IFIP Code of Ethics, especially its sections on organizational ethics and international concerns. The ethical obligations of organizations tend to be neglected in most codes of professional conduct, perhaps because these codes are written from the perspective of the individual member. This dilemma is addressed by stating these imperatives from the perspective of the organizational leader. In this context "leader" is viewed as any organizational member who has leadership or educational responsibilities. These imperatives generally may apply to organizations as well as their leaders. In this context "organizations" are corporations, government agencies, and other "employers," as well as volunteer professional organizations.

\subsection{Articulate social responsibilities of members of an organizational unit and encourage full acceptance of those responsibilities}

Because organizations of all kinds have impacts on the public, they must accept responsibilities to society. Organizational procedures and attitudes oriented toward quality and the welfare of society will reduce harm to members of the public, thereby serving public interest and fulfilling social responsibility. Therefore,organizational leaders must encourage full participation in meeting social responsibilities as well as quality performance.

\subsection{Manage personnel and resources to design and build information systems that enhance the quality of working life}

Organizational leaders are responsible for ensuring that computer systems enhance, not degrade, the quality of working life. When implementing a computer system, organizations must consider the personal and professional development, physical safety, and human dignity of all workers. Appropriate human-computer ergonomic standards should be considered in system design and in the workplace.

\subsection{Acknowledge and support proper and authorized uses of an organization's computing and communication resources}

Because computer systems can become tools to harm as well as to benefit an organization, the leadership has the responsibility to clearly define appropriate and inappropriate uses of organizational computing resources. While the number and scope of such rules should be minimal, they should be fully enforced when established. 
3.4 Ensure that users and those who will be affected by a system have their needs clearly articulated during the assessment and design of requirements; later the system must be validated to meet requirements

Current system users, potential users and other persons whose lives may be affected by a system must have their needs assessed and incorporated in the statement of requirements. System validation should ensure compliance with those requirements.

\subsection{Articulate and support policies that protect the dignity of users and others affected by a computing} system

Designing or implementing systems that deliberately or inadvertently demean individuals or groups is ethically unacceptable. Computer professionals who are in decision making positions should verify that systems are designed and implemented to protect personal privacy and enhance personal dignity.

\subsection{Create opportunities for members of the organization to learn the principles and limitations of computer systems}

This complements the imperative on public understanding (2.7). Educational opportunities are essential to facilitate optimal participation of all organizational members. Opportunities must be available to all members to help them improve their knowledge and skills in computing, including courses that familiarize them with the consequences and limitations of particular types of systems.In particular, professionals must be made aware of the dangers of building systems around oversimplified models, the improbability of anticipating and designing for every possible operating condition, and other issues related to the complexity of this profession.

\section{COMPLIANCE WITH THE CODE}

As an ACM member I will ...

\subsection{Uphold and promote the principles of this Code}

The future of the computing profession depends on both technical and ethical excellence. Not only is it important for ACM computing professionals to adhere to the principles expressed in this Code, each member should encourage and support adherence by other members.

\subsection{Treat violations of this code as inconsistent with membership in the ACM}

Adherence of professionals to a code of ethics is largely a voluntary matter. However, if a member does not follow this code by engaging in gross misconduct, membership in ACM may be terminated.

This Code and the supplemental Guidelines were developed by the Task Force for the Revision of the ACM Code of Ethics and Professional Conduct: Ronald E. Anderson, Chair, Gerald Engel, Donald Gotterbarn, Grace C. Hertlein, Alex Hoffman, Bruce Jawer, Deborah G. Johnson, Doris K. Lidtke, Joyce Currie Little, Dianne Martin, Donn B. Parker, Judith A. Perrolle, and Richard S. Rosenberg. The Task Force was organized by ACM/SIGCAS and funding was provided by the ACM SIG Discretionary Fund. This Code and the supplemental Guidelines were adopted by the ACM Council on October 16, 1992.

This Code may be published without permission as long as it is not changed in any way and it carries the copyright notice. (Copyright ACM)

http://www.acm.org/about/code-of-ethics?searchterm=code+of+ethics 